\title{
Gangguan Mental Emosional dan Kesepian pada Mahasiswa Baru
}

\author{
Clement Eko Prasetio ${ }^{(1)}$, Tiffani Amalia Rahman ${ }^{(1)}$, Airin Triwahyuni ${ }^{(1)}$ \\ ${ }^{(1)}$ Fakultas Psikologi, Universitas Padjadjaran, Sumedang, Indonesia
}

\begin{abstract}
In the transition period from high school to college, freshmen have to deal with the new environment, which makes them vulnerable to experience symptoms of mental disorders. The aim of the current study was to examine the role of loneliness as a predictor of symptoms of mental disorders among freshmen. Using a convenience sampling, 151 first-year undergraduate students from one faculty at Universitas Padjadjaran took part in the current study. The respondents completed a self-report questionnaire consisting of WHO Self-Report Questionnaire (SRQ) to assess symptoms of mental disorders and UCLA Loneliness scale to assess loneliness. The result showed that loneliness significantly predicted symptoms of mental disorders among freshmen. Theoretical implications of these empirical findings are discussed, as are practical implications highlighting the suggestions for the university stakeholders to implement an intervention that is effective in tackling freshmen's mental disorders such as social skill training, increasing social support, and increasing probability of social contact.
\end{abstract}

Keywords: emotional disorder, loneliness, freshmen, transition

Pada masa transisi dari sekolah menengah atas ke perkuliahan, mahasiswa harus menyesuaikan diri dengan lingkungan barunya. Akibatnya, pada masa ini mahasiswa sering mengalami gejalagejala gangguan mental emosional. Tujuan penelitian ini adalah untuk menguji peran perasaan kesepian dalam memprediksi gangguan mental emosional di kalangan mahasiswa baru. Melalui penarikan sampel yang bersifat convenient, sebanyak 151 mahasiswa baru pada salah satu fakultas di Universitas Padjadjaran berpartisipasi dalam penelitian ini. Metode pengumpulan data menggunakan kuesioner yaitu Self Report Questionnaire (SRQ) untuk mengukur gejala gangguan mental emosional dan UCLA Loneliness Scale untuk mengukur tingkat kesepian. Hasil penelitian ini menunjukkan bahwa kesepian dapat menjadi prediktor gangguan mental emosional pada mahasiswa baru. Implikasi teoretis dari temuan ini kami diskusikan, dan juga implikasi praktis yang menekankan pada pentingnya bagi pihak universitas untuk menerapkan sebuah intervensi yang efektif dalam menangani gangguan mental emosional di kalangan mahasiswa baru, seperti pemberian pelatihan keterampilan sosial, peningkatan dukungan sosial serta kontak sosial.

Kata kunci: gangguan mental emosional, kesepian, mahasiswa baru, masa transisi

MEDIAPSI, 2019, Vol. 5(2), 97-107, DOI: https://doi.org/10.21776/ub.mps.2019.005.02.4

Received: 2019-07-24. Revised: 2019-09-06. Accepted: 2019-11-05. Published online: 2019-12-05

Handling Editor: Sumi Lestari, Universitas Brawijaya, Malang, Indonesia

*Corresponding author: Clement Eko Prasetio, Fakultas Psikologi, Universitas Padjadjaran, Sumedang, Indonesia

E-mail: clement17001@mail.unpad.ac.id

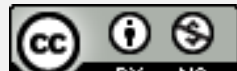

This work is licensed under a Creative Commons Attribution-NonCommercial 4.0 International License.

How to cite this article in accordance with the American Psychological Association (APA) $6^{\text {th }}$ guidelines:

Prasetio, C. E., Rahman, T. A., \& Twiwahyuni, A. (2019). Gangguan mental emosionaldan kesepian pada mahasiswa baru. MEDIAPSI, 5(2), 97-107. DOI: https://doi.org/10.21776/ub.mps.2019.005.02.4

\section{Pendahuluan}

Masa transisi dari siswa sekolah menengah atas (SMA) menuju mahasiswa merupakan masa yang sulit dimana mereka dituntut untuk menyesuaikan diri dari kehidupan sekolah ke kehidupan di perkuliahan (Gonzalez-Espada \& Napoleoni-Milan, 2006; Ruberman, 2014). Pada masa ini, remaja perlu menyesuaikan diri 
dengan kehidupan di perkuliahan. Ada banyak aspek perubahan yang dialami oleh mahasiswa baru. Aspek-aspek perubahan ini terejawantah dalam bentuk masalah-masalah sosial, akademik, dan personal, baik yang terkait dengan, misalnya, perubahan sistem pendidikan, keharusan meninggalkan rumah dan tinggal jauh dari orang tua, serta pertemuan dengan banyak orang (Gall, Evans, \& Bellerose, 2000; Kerig \& Schulz, 2012; Mounts, 2004; Newman \& Newman, 2011).

Beberapa penelitian menunjukkan bahwa banyak mahasiswa baru yang mengalami gangguan mental emosional. Prevalensi gangguan mental emosional yang terjadi pada mahasiswa baru tergolong tinggi, yaitu sebesar 12\% hingga 50\% (Blanco dkk., 2008; Hunt \& Eisenberg, 2010; Verger, Guagliardo, Gilbert, Rouillon, \& Kovess-Masfety, 2010). Penemuan lain menyatakan bahwa sebanyak $30 \%$ mahasiswa baru mengalami distress psikologis, seperti kecemasan dan depresi (Adlaf, Gliksman, Demers, \& Newton-Taylor, 2001). Di Amerika Serikat, ada temuan bahwa 13.8\% mahasiswa mengalami depresi (American College Health Association, 2015). Tingginya prevalensi gangguan mental emosional pada mahasiswa baru juga terjadi di Indonesia. Penelitian di salah satu universitas di Jakarta menemukan bahwa $12.7 \%$ mahasiswa mengalami gangguan mental emosional (Vidiawati, Iskandar, \& Agustian, 2018). Hasil penelitian lain yang dilakukan di Universitas Udayana menyatakan bahwa sebanyak $29.31 \%$ mahasiswa baru mengalami gejala klinis yang mengindikasikan depresi berat (Karin, 2017).

Gangguan mental emosional adalah keadaan yang mengindikasikan bahwa individu mengalami suatu perubahan emosional yang dapat berkembang menjadi keadaan patologis. Jika terus berlanjut maka perubahan emosioanal tersebut perlu diantisipasi agar kesehatan jiwa masyarakat tetap terjaga (Idaiani, Suhardi, \& Kristanto, 2009). Beberapa penelitian di Indonesia menemukan bahwa gangguan mental emosional, khususnya gangguan neurosis, bisa dibagi ke dalam empat dimensi: (1) penurunan energi, (2) gangguan somatik, (3) perasaan depresif, dan (4) pemikiran depresif (Idaiani dkk., 2009; Vidiawati dkk., 2018).

Gejala gangguan mental emosional dapat mempengaruhi fungsi kehidupan seharihari mahasiswa, baik dalam fungsi sosial, akademik maupun fisik. Individu dengan gangguan mental emosional yang berkepanjangan bisa mengalami kegagalan dalam menjalani relasi dan menderita beberapa penyakit fisik (Adams, Wharton, Quilter, \& Hirsch, 2008; Bruffaerts dkk., 2018). Selain itu, mahasiswa yang mengalami gangguan mental emosional juga dilaporkan cenderung mengalami penurunan nilai akademis. Gangguan mental emosional pada mahasiswa juga berkaitan dengan tingkat putus sekolah (Bruffaerts dkk., 2018).

Tingginya prevalensi mahasiswa baru yang mengalami gangguan mental emosional ternyata belum banyak menjadi perhatian para peneliti di Indonesia. Fokus beberapa penelitian terdahulu bukan pada mahasiswa baru, melainkan pada siswa sekolah dasar (Prihatiningsih \& Wijayanti, 2019), anak berusia 5 sampai 14 tahun (Isfandari \& Suhardi, 1997), masyarakat umum berusia 15 atau 25 sampai 65 tahun (Idaiani, Sapardin, \& Sulistiowati, 2015; Kementerian Kesehatan Republik Indonesia, 2018).

Salah satu faktor yang berkontribusi pada masalah gangguan mental emosional mahasiswa yaitu kesepian (loneliness) yang dialami mahasiswa pada masa transisi. Kesepian adalah perasaan emosional yang tidak menyenangkan dimana individu-individu yang mengalaminya mempersepsikan bahwa hubungan sosial yang mereka harapkan kurang teraktualisasikan. Persepsi ini diakibatkan oleh perasaan terisolasi dari lingkungan sosial (Cacioppo, Capitanio, \& Cacioppo, 2014; Hawkley \& Cacioppo, 2010). Menurut teori kebutuhan, manusia memiliki kebutuhan untuk berafiliasi, yaitu suatu kebutuhan untuk berhubungan, merasa terlibat dan menjadi 
bagian dari kelompok sosial di sekitarnya (McClelland, 1961).

Pada masa transisi, mahasiswa masih beradaptasi dengan lingkungan sekitarnya dan belum melekat (attach) dengan lingkungan sosialnya sehingga sering mengalami kesepian (Wei, Russell, \& Zakalik, 2005). Selain itu, kesepian dapat berhubungan dengan depresi, karena ketika seseorang merasa kesepian, ada kecenderungan untuk lebih memperhatikan halhal negatif. Ketika seseorang terus menerus memperhatikan hal negatif, maka hal ini memantik stres pada dirinya atau bahkan depresi (Wenzlaff \& Bates, 1998). Kesepian berkaitan dengan gangguan mental emosional seperti depresi dan kecemasan pada mahasiswa baru (Brandy, Penckofer, Solari-Twadell \& Velsor-Friedrich, 2015; Moeller \& Seehuus, 2019). Penelitian di beberapa negara, seperti Inggris, Rusia, dan Swiss telah menyebutkan kesepian sebagai variabel yang berhubungan dan/atau menyebabkan munculnya gangguan mental emosional, seperti depresi, kecemasan, stres dan gangguan somatik (Richardson, Elliot, \& Roberts, 2017; Rohrmann dkk., 2017; Stickley dkk., 2016).

Sebuah penelitian mengemukakan bahwa sebagian besar mahasiswa baru mengalami kesepian akut dan isolasi (Berman \& Sperling, 1991). Penelitian yang dilakukan di University of Gondar di Etiopia melaporkan bahwa prevalensi kesepian pada mahasiswa baru sebesar 49.5\% (Dagnew \& Dagne, 2019). Penelitian mengenai kesepian yang dilakukan di Universitas Diponegoro menemukan bahwa kesepian pada mahasiswa baru bisa diprediksi melalui penyesuaian diri mahasiswa (Prasetia \& Hartati, 2014). Berdasarkan penelitianpenelitian yang dilakukan sebelumnya, penelitian ini bertujuan untuk menguji apakah kesepian dapat digunakan sebagai prediktor munculnya gejala gangguan mental emosional pada mahasiswa baru. Selain itu, penelitian ini juga bertujuan untuk memberikan gambaran mengenai tingkat gangguan mental emosional dan kesepian pada mahasiswa baru.

\section{Metode}

\section{Desain penelitian}

Pendekatan penelitian yang digunakan dalam penelitian ini adalah pendekatan kuantitatif, dengan jenis penelitian crosssectional study yang dilaksanakan pada bulan Mei 2018.

\section{Responden penelitian}

Responden penelitian ini adalah mahasiswa baru semester dua pada salah satu fakultas di Universitas Padjadjaran sebanyak 151 (121 wanita dan 30 pria). Teknik sampling yang digunakan untuk merekrut responden adalah convenience sampling. Alasan pemilihan convenience sampling ini adalah karena penulis mengobservasi adanya fenomena gangguan mental emosional pada mahasiswa baru. Selain itu, penulis memilih mahasiswa semester dua karena mahasiswa semester dua diasumsikan sudah dapat beradaptasi dengan lingkungan sosialnya. Berdasarkan DSM-5, individu dikatakan mengalami gangguan penyesuaian diri jika gangguan tersebut dialami lebih dari enam bulan, sehingga mahasiswa baru yang masih belum dapat menyesuaikan diri setelah satu semester atau sekitar enam bulan perkuliahan dapat dikatakan mengalami gangguan (American Psychiatric Association, 2013).

\section{Instrumen penelitian}

Proses pengambilan data menggunakan kuesioner kertas yang dibagikan kepada para mahasiswa dan berlangsung selama 30 menit. Peneliti terlebih dahulu memberikan penjelasan kepada responden mengenai tujuan penelitian, waktu penelitian, dan kerahasiaan. Kemudian responden diminta untuk mengisi lembar kesediaan terlebih dahulu.

Penelitian ini menggunakan dua alat ukur. Pertama adalah Self-Report Questionnaire (SRQ; World Health Organization, 1994) yang mengukur gejala gangguan mental emosional menggunakan 20 butir pertanyaan. Penulis menggunakan hasil terjemahan alat ukur yang telah dilakukan oleh tim dari Pusat Studi Psikometri, Asesmen, dan Evaluasi Program 
Fakultas Psikologi Universitas Padjajaran. Melalui confirmatory factor analysis (CFA), Angela (2018) menemukan bahwa validitas alat ukur tersebut adalah meyakinkan (root mean square error of approximation [RMSEA] = 0.046, comparative fit index $[\mathrm{CFI}]=0.941$, Tucker Lewis index [TLI]= 0.929). Kemudian, penulis menghitung reliabilitas alat ukur dan didapatkan bahwa alat ukur memiliki nilai reliabilits yang bagus (Cronbach alpha/ $\alpha=$ 0.796). Setiap pertanyaan memiliki dua pilihan jawaban yaitu "ya" dan "tidak". Jika responden menjawab "ya" maka diberikan nilai 1, jika responden menjawab "tidak" maka diberikan nilai 0 .

Alat ukur kedua adalah adalah UCLA Loneliness Scale versi 3 yang mengukur tingkat kesepian menggunakan 20 pertanyaan. Kuesioner ini memiliki nilai reliabilitas yang meyakinkan ( $\alpha=0.916)$. Umiroh (2019) juga telah menguji bahwa validasi alat ukur tersebut meyakinkan (RMSEA $=0.06, \mathrm{CFI}=0.99)$ Skor untuk jawaban terhadap setiap pernyataan dalam alat ukur ini bervariasi dari 1 (tidak pernah), 2 (jarang), 3 (kadang-kadang), dan 4 (sering). Kuesioner ini hanya memiliki satu dimensi (unidimentional) yaitu social relationship.

Selain kuesioner SRQ dan UCLA Loneliness Scale, peneliti juga menanyakan beberapa informasi, misalnya jumlah teman dekat di fakultas yang sama dan di luar fakultas serta teman dekat semasa SMA. Variabel penelitian terdiri dari variabel bebas (prediktor) dan variabel tergantung (kriterium). Prediktor yang digunakan adalah tingkat kesepian (X1), sedangkan kriteriumnya adalah gangguan mental emosional. Pengolahan data dilakukan menggunakan program SPSS. Teknik analisis yang digunakan dalam penelitian ini adalah simple linear regression.

\section{Hasil}

Tabel 1 di bawah ini menjelaskan tentang statistik deskriptif dari gangguan mental emosional yang memiliki rata-rata yang tinggi.
Sementara itu, tingkat kesepian cenderung sedang. Mahasiswa yang mengalami gangguan mental emosional sebanyak 120 mahasiswa atau sekitar $79.5 \%$ yang menjawab "ya" lebih atau sama dengan enam pada kuesioner SRQ.

Tabel 1. Statistik Deskriptif Gangguan Mental Emosional dan Kesepian

\begin{tabular}{lcc}
\hline Variabel & $N$ & $M(S D)$ \\
\hline Gangguan Mental & 151 & $0.79(0.41)$ \\
Emosional & 151 & $39.08(9.57)$ \\
Kesepian &
\end{tabular}

Keterangan: $N=$ jumlah responden; $M=$ mean atau rata-rata, $S D$

$=$ deviasi standard.

Tabel 2. Loneliness sebagai Prediktor Gangguan Mental Emosional

\begin{tabular}{ccccc}
\hline Variabel & $B$ & $S E$ & $\beta$ & $95 \% C I$ \\
\hline Loneliness & $0.274^{* *}$ & 0.032 & 0.578 & {$[0.21,0.34]$} \\
$R^{2}$ & .334 & - & - & - \\
$F$ & $74.58^{* *}$ & - & - & - \\
\hline
\end{tabular}

Keterangan: $B=$ koefisien regresi unstandardised; $S E=$ eror standar; $\beta$ $=$ koefisien regresi terstandar; $C I=$ interval konfidensi; $R^{2}=$ Sumbangan efektif; $F=$ signifikansi persamaan regresi; $* p<.05 . * * p .01$.

Tabel 2 di atas menampilkan hasil uji analisis regresi, yang menunjukkan bahwa kesepian menjadi prediktor yang signifikan gangguan mental emosional. Kesepian dapat menjelaskan $33.4 \%$ variansi dari gangguan mental emosional. Kesepian memiliki effect size yang tergolong besar dalam memprediksi gangguan mental emosional, yaitu cohen's $f^{2}=$ 0.501. Berdasarkan hasil pada Tabel 2, persamaan regresi yang diperoleh adalah $\mathrm{Y}=$ $0.274 \mathrm{X} 1$. Persamaan regresi ini mengandung arti bahwa ketika nilai kesepian meningkat dalan satu unit pengukuran, maka nilai gangguan mental emosional akan bertambah sebesar 0.274 .

\section{Diskusi}

Berdasarkan pada hasil analisis data sebagaimana telah dijelaskan di atas, kesepian secara signifikan dapat memprediksi ke arah positif gangguan mental emosional. Hal ini berarti bahwa tingginya tingkat kesepian mahasiswa baru dapat menjadi prediktor untuk munculnya gejala gangguan mental emosional pada mahasiswa tersebut. Hasil tersebut sesuai 
dengan penelitian-penelitian terdahulu yang mengungkapkan bahwa kesepian berhubungan dengan gangguan mental emosional, seperti depresi, gangguan somatik ataupun kecemasan (Rohrmann dkk., 2017; Stickley dkk., 2016). Sebuah penelitian di Inggris juga menyebutkan bahwa kesepian dapat memprediksi munculnya kecemasan, stres, depresi, dan kesehatan mental secara umum (Richardson dkk., 2017).

Persentase mahasiswa baru yang mengalami gangguan mental emosional pada salah satu fakultas di Universitas Padjadjaran tergolong tinggi (79.5\%) jika dibandingkan dengan penelitian-penelitian sebelumnya baik di Indonesia maupun di negara-negara barat. Penelitian di Indonesia yang dilakukan oleh sebuah universitas di Jakarta dan Universitas Udayana menemukan sebanyak 12 sampai dengan $30 \%$ mahasiswa baru mengalami gangguan mental emosional (Idaiani dkk., 2009; Karin, 2017). Demikian pula di Amerika dan Perancis, hasil penelitian menunjukan prevalensi gangguan mental emosional yang lebih rendah (American College Health Association, 2015; Blanco dkk., 2008; Hunt \& Eisenberg, 2010; Verger dkk., 2010). Kondisi ini mungkin berhubungan dengan pengetahuan mahasiswa yang menjadi partisipan penelitian dimana mereka mempelajari beberapa gangguan mental sehingga lebih mudah mengatribusikan gejala gangguan mental pada diri mereka sendiri. Pengetahuan mengenai gangguan mental, baik yang diperoleh dari proses akademik maupun sumber lain seperti media massa adalah salah satu faktor penyebab mahasiswa melakukan diagnosa diri (Ahmed \& Samuel, 2017).

Kesepian memiliki hubungan dengan munculnya gangguan mental emosional. Perasaan kesepian seringkali dikatakan sebagai salah satu sumber stres psikologis (Beutel dkk., 2017; Schneiderman, Ironson, \& Siegel, 2005). Secara biologis, kondisi stres dapat meningkatkan aktivitas hormonal dan sistem saraf otonom (Cannon 1929; Hess, 1959). Sebagai akibatnya, stres memunculkan gejala- gejala fisik, misalnya detak jantung meningkat, asam lambung meningkat, dan lain-lain. Dalam jangka panjang, gejala-gejala psikologis juga berpotensi untuk muncul, misalnya perasaanperasaan lelah secara psikologi, tidak berharga, mudah marah atau sedih, serta kesulitan berkonsentrasi, dan lain sebagainya.

Penelitian lain yang terkait kesepian menyebutkan bahwa kesepian bersifat seperti loop atau memutar, yaitu ketika seseorang mempersepsi dirinya mengalami isolasi sosial, maka persepsi ini akan mendorong munculnya kesepian. Orang yang merasa kesepian akan cenderung melihat dunia sosialnya sebagai dunia yang berbahaya. Hal tersebut akan membuat dirinya secara tidak sadar menjaga jarak dengan dunia luar, yang memungkinkan terjadinya kesepian yang lebih tinggi lagi. Hawkley dan Cacioppo (2010) menjelaskan bahwa proses loneliness loop seringkali menimbulkan perasaan permusuhan, stres, pesimisme, kecemasan, dan rendahnya selfesteem, serta mengaktifkan aktivitas neurobiologis dan mekanisme perilaku yang bisa mengganggu kesehatan.

Penelitian ini menambah informasi mengenai tingkat gangguan mental emosional yang terjadi pada mahasiswa baru di Indonesia. Hubungan antara kesepian dan gangguan mental emosional pada beberapa penelitian di luar negeri (Rohrmann dkk., 2017; Stickley dkk., 2016) hanya berupa korelasi saja. Di Indonesia sendiri, masih sedikit yang membahas mengenai hubungan kesepian dan gangguan mental emosional pada mahasiswa baru. Maka, penelitian ini dapat memberikan tambahan informasi bahwa kesepian dapat memprediksi gangguan mental emosional pada mahasiswa baru.

Sebagai tambahan, peneliti ini juga mengambil data demografis terkait dengan asalusul SMA dan jumlah teman dekat dari responden. Data tersebut peneliti ambil bersama-sama dengan kuesioner UCLA dan SRQ-20. Berdasarkan data yang diperoleh, sebanyak 113 responden (87\%) berasal dari 
SMA di luar Bandung dan sekitarnya (Cimahi, Lembang, maupun Jatinangor). Tinggal terpisah dari orang tua dan jauh dari rumah mungkin menjadi salah satu faktor yang menyebabkan responden yang SMAnya bukan dari Kota Bandung dan sekitarnya mengalami kesepian yang berpotensi memunculkan gejala gangguan mental emosional. Hal ini selaras dengan penelitian yang mengatakan bahwa tinggal terpisah dari orang tua dan jauh dari rumah bisa membuat mahasiswa merasa kesepian (Elizabeth \& Sigal, 2001). Selain itu, penelitian yang dilakukan pada salah satu fakultas di Universitas Padjadjaran juga mengungkapkan bahwa tinggal terpisah dari orang tua atau rumah berkorelasi positif dengan kesepian (Umiroh, 2019).

Penelitian ini juga menanyakan jumlah teman dekat yang dimiliki oleh masing-masing responden. Data menunjukkan bahwa sebanyak 127 responden (84\%) memiliki jumlah teman dekat yang lebih banyak di luar fakultas mereka. Bahkan, terdapat 17 orang dari keseluruhan responden yang menganggap dirinya tidak memiliki teman dekat di fakultas yang sama. Sedikitnya jumlah teman dekat di fakultas yang sama mungkin saja mendorong munculnya kesepian. Selain itu, 15 dari 17 responden yang tidak memiliki teman dekat di fakultas yang sama mengalami gangguan mental emosional. Penemuan ini sesuai dengan sebuah penelitian di Belanda yang menyatakan bahwa kesepian berkorelasi negatif dengan jumlah teman pada remaja. Remaja yang hanya memiliki sedikit teman dekat cenderung merasa kesepian (Lodder, Scholte, Goossens, \& Verhagen, 2017).

Kesimpulan yang bisa diambil berdasarkan hasil analisis yang telah dilakukan adalah bahwa tingkat kesepian memprediksi munculnya gangguan mental emosional pada mahasiswa baru. Temuan yang lain menunjukkan bahwa banyak mahasiswa baru yang tidak memiliki teman dekat di fakultas yang sama. Hal ini mungkin mendorong terjadinya kesepian. Orang yang merasa kesepian akan cenderung memperhatikan halhal negatif di lingkungan sekitar sehingga memperburuk kondisi psikologisnya dan memungkinkan munculnya gangguan mental emosional. Penelitian ini juga menemukan bahwa lebih dari 50\% mahasiswa baru mengalami gangguan mental emosional. Hasil penelitian menunjukkan bahwa kesepian dapat menjadi prediktor munculnya gejala gangguan mental emosional. Oleh karena itu, mengurangi tingkat kesepian pada mahasiswa baru dapat mengurangi tingkat gangguan mental emosional yang dialami oleh mahasiswa baru.

Terdapat beberapa keterbatasan pada penelitian ini. Keterbatasan pertama terkait dengan sampel yang hanya berasal dari satu fakultas yang memiliki pengetahuan mengenai gangguan mental. Pengetahuan mengenai gangguan mental berpotensi meningkatkan persentase mahasiswa untuk menjawab lebih banyak gejala gangguan mental. Penelitian ini juga belum bisa menjelaskan dan mengidentifikasi penyebab kesepian yang dapat digunakan untuk memprediksi gangguan mental emosional pada mahasiswa baru.

Untuk memperbaiki keterbatasan tersebut, penelitian selanjutnya disarankan untuk menggunakan sampel mahasiswa baru yang lebih besar. Penelitian lanjutan juga bisa menggunakan teknik pengambilan data yang lebih komprehensif, misalnya menggunakan teknik survei dan teknik wawancara atau observasi. Penggunaan metode longitudinal juga disarankan untuk digunakan, agar bisa lebih menggambarkan dinamika yang terjadi pada variabel-variabel penelitian. Variabel kesepian hanya dapat menjelaskan $33.4 \%$ variansi dari gangguan mental emosional. Hal ini berarti bahwa ada beberapa variabel lain yang bisa diikutsertakan ke dalam model untuk untuk menjelaskan variansi dari gangguan mental emosional. Variabel-variabel tersebut diantaranya adalah psychological well-being (Liu, Shono, \& Kitamura, 2009; Ryff \& Keyes, 1996), self-esteem (Orth, Robins, Widaman, \& Conger, 2014; Park \& Yang, 2017), dan social 
support (Hefner \& Eisenberg, 2009; Jibeen, 2016; Reid, Holt, Bowman, Espelage, \& Green, 2016).

Saran praktis dari hasil penelitian ini terkait dengan isu masa orientasi. Kegiatankegiatan pada masa orientasi lebih baik digunakan untuk untuk mencegah atau mengurangi munculnya kesepian pada mahasiswa baru. Intervensi yang mungkin bisa dilakukan adalah memberikan pelatihan yang ditujukan untuk meningkatkan keterampilan sosial (social skill training), dukungan sosial dan kemungkinan kontak sosial (Masi dkk., 2010). Pelatihan keterampilan sosial dapat dimasukan ke dalam rangkaian masa orientasi mahasiswa baru sehingga mereka diharapkan memiliki keterampilan yang mencukupi untuk bisa bersosialisasi dengan baik. Sementara itu, peningkatan dukungan sosial dapat dilakukan dengan cara membangun iklim yang mendukung (supportive) ataupun membuat peer counselor. Meningkatkan kontak sosial dapat dilakukan dengan merancang metode pembelajaran yang dapat membuat mahasiswa saling berinteraksi seperti diskusi kelompok dan kerja tim. Kontak sosial yang baik akan meningkatkan kedekatan di antara mahasiswa sehingga mengurangi kesepian.

\section{Daftar Pustaka}

Adams, T. B., Wharton, C. M., Quilter, L., \& Hirsch, T. (2008). The association between mental health and acute infectious illness among a national sample of 18- to 24-year-old college students. Journal of American College Health, 56(6), 657-663. https://doi.org/10.3200/JACH.56.6.657664

Adlaf, E. M., Gliksman, L., Demers, A., \& Newton-Taylor, B. (2001). The prevalence of elevated psychological distress among canadian undergraduates: Findings from the 1998 Canadian campus survey. Journal of the American College Health Association, 50(2), 67-72. https://doi.org/10.1080/074484801095960 09

Ahmed, A., \& Samuel, S. (2017). Selfdiagnosis in psychology students. The International Journal of Indian Psychology, 5(1), 148-164. DOI: $10.25215 / 0501.036$

American College Health Association. (2015). National college health Assessment. Spring 2014 Reference Group Executive Summary. Hanover, MD. Diakses dari http://www.acha-ncha.org/reports ACHANCHAAII.html

American Psychiatric Association. (2013).

Diagnostic and statistical manual of mental disorder (DSM-5). American Psychiatric Association (5 $5^{\text {th }}$ ed.). VA: American Psychiatric Association. https://doi.org/10.1192/bjp.111.479.1009-a Angela. (2018). "Strategi coping sebagai mediator dalam pengaruh stres terhadap kesehatan mental mahasiswa Universitas Padjadjaran (skripsi). Universitas Padjadjaran, Bandung, Indonesia.

Berman, W. H., \& Sperling, M. B. (1991). Parental attachment and emotional distress in the transition to college. Journal of Youth and Adolescence, 20(4), 427-440. https://doi.org/10.1007/BF01537184

Beutel, M. E., Klein, E. M., Brähler, E., Reiner, I., Jünger, C., Michal, M., ... Tibubos, A. N. (2017). Loneliness in the general population: Prevalence, determinants and relations to mental health. $B M C$ Psychiatry, 17(1), 1-7. https://doi.org/10.1186/s12888-017-1262$\mathrm{x}$

Blanco, C., Okuda, M., Wright, C., Hasin, D. S., Grant, B. F., Liu, S. M., \& Olfson, M. (2008). Mental health of college students and their non-college-attending peers: Results from the national epidemiologic study on alcohol and related conditions. Archives of General Psychiatry, 65(12), 1429-1437.

https://doi.org/10.1001/archpsyc.65.12.142 
9

Brandy, J. M., Penckofer, S., Solari-Twadell, P. A., \& Velsor-Friedrich, B. (2015). Factors predictive of depression in first-year college students. Journal of Psychosocial Nursing and Mental Health Services, 53(2), $38-44$. https://doi.org/10.3928/0279369520150126-03

Bruffaerts, R., Mortier, P., Kiekens, G., Auerbach, R. P., Cuijpers, P., Demyttenaere, K., ... Kessler, R. C. (2018b). Mental health problems in college freshmen: Prevalence and academic functioning. Journal of Affective Disorders, 225, 97-103. https://doi.org/10.1016/j.jad.2017.07.044

Cacioppo, S., Capitanio, J. P., \& Cacioppo, J. T. (2014). Toward a neurology of loneliness. Psychological Bulletin, 140(6), 1464-1504. https://psycnet.apa.org/doi/10.1037/a0037 618

Cannon, W.B. (1929). Bodily changes in pain, hunger, fear and rage. New York: Appleton.

Dagnew, B., \& Dagne, H. (2019). Year of study as predictor of loneliness among students of University of Gondar. BMC Research Notes, 12(1), 1-6. https://doi.org/10.1186/s13104-019-42744

Elizabeth, L. P., \& Sigal, B. (2001). Friendsickness in the transition to college: Precollege predictors and college adjustment correlates. Journal of Counseling \& Development, 79, 77-89. https://doi.org/10.1002/j.15566676.2001.tb01946.x

Gall, T. L., Evans, D. R., \& Bellerose, S. (2000). Transititon to first year university: Patterns of change in adjustment across life domains and time. Journal of Social and Clinical Psychology, 19(4), 544-567. https://doi.org/10.1521/jscp.2000.19.4.54 4
Gonzalez-Espada, W. J., \& Napoleoni-Milán, R. L. (2006). The highschool-to-college transition in science. In J. Mintzes \& W. Leonard (Eds.), Handbook of college science teaching (pp. 351-357. Arlington, VA, USA: National Science Teachers Association Press.

Hawkley, L. C., \& Cacioppo, J. T. (2010). Loneliness matters: A theoretical and empirical review of consequences and mechanisms. Annals of Behavioral Medicine, 40(2), 218-227. https://doi.org/10.1007/s12160-010-92108

Hefner, J., \& Eisenberg, D. (2009). Social support and mental health among college students. American Journal of Orthopsychiatry, 79(4), 491-499. https://doi.org/10.1037/a0016918

Hess, W.R .(1957). Functional organization of the diencephalons. NewYork: Grune \& Stratton.

Hunt, J., \& Eisenberg, D. (2010). Mental health problems and help-seeking behavior among college students. Journal of Adolescent Health, 46(1), 3-10. https://doi.org/10.1016/j.jadohealth.2009. 08.008

Idaiani, S., Suhardi, S., \& Kristanto, A. Y. (2009). Analisis gejala gangguan mental emosional penduduk Indonesia. Journal Kedokteran Indonesia, 59(10), 473-479.

Idaiani, S., Sapardin, A. N., \& Sulistiowati, E. (2015). Gambaran kohor 2011-2013 gangguan mental emosional berdasarkan SRQ-20 pada penduduk kelurahan Kebon Kalapa Bogor. Buletin Penelitian Kesehatan, 43(4), 273-278. DOI: 10.22435/bpk.v43i4.4604.273-278

Isfandari, S., \& Suhardi. (1997). Gejala gangguan mental emosional pada anak. Buletin Penelitian Kesehatan, 25(38 4), 53-60. Diakses dari http://ejournal.litbang.depkes.go.id/index. $\mathrm{php} / \mathrm{BPK} / \mathrm{article} / \mathrm{view} / 301$

Jibeen, T. (2016). Perceived social support and 
mental health problems among Pakistani university students. Community Mental Health Journal, 52(8), 1004-1008. https://doi.org/10.1007/s10597-015-99438

Karin, P. A. E. S. (2017). Gambaran tingkat depresi pada mahasiswa tingkat pertama program studi Ilmu Keperawatan Fakultas Kedokteran Universitas Udayana (laporan penelitian). Universitas Udayana, Bali, Indonesia. Diakses dari https://simdos.unud.ac.id/uploads/file_pe nelitian_1_dir/730f53e2b7c197cc23053e1 83efd3704.pdf

Kementerian Kesehatan Republik Indonesia. (2018). Riset kesehatan dasar Indonesia (Riskesdas) 2018. Jakarta: Kementerian Kesehatan Republik Indonesia.

Kerig, P. K., \& Schulz, M. S. (2012). The transition from adolescence to adulthood: What lies beneath and what lies beyond. In P. K. Kerig, M. S. Schulz, \& S. T. Hauser (Eds.), Adolescence and beyond: Family processes and development (pp. 3-12). MA: Oxford University Press.

Liu, Q., Shono, M., \& Kitamura, T. (2009). Psychological well-being, depression, and anxiety in Japanese university students. Depression and Anxiety, 26(8), 99-105. https://doi.org/10.1002/da.20455

Lodder, G. M. A., Scholte, R. H. J., Goossens, L., \& Verhagen, M. (2017). Loneliness in early adolescence: Friendship quantity, friendship quality, and dyadic processes. Journal of Clinical Child and Adolescent Psychology, 46(5), 709-720. https://doi.org/10.1080/15374416.2015.10 70352

Masi, C. M., Chen, H. Y., Hawkley, L. C., \& Cacioppo, J. T. (2011). A meta-analysis of interventions to reduce loneliness. Personality and Social Psychology Review, 15(3), 219-266. https://doi.org/10.1177\%2F10888683103 77394

McClelland, D. (1961). The achieving society.
Princeton, NJ: Van Nostrand Company Inc.

Moeller, R. W., \& Seehuus, M. (2019). Loneliness as a mediator for college students' social skills and experiences of depression and anxiety. Journal of Adolescence, 73, $1-13$. https://doi.org/10.1016/j.adolescence.201 9.03.006

Mounts, N. S. (2004). Contributions of parenting and campus climate to freshmen adjustment in a multiethnic sample. Journal of Adolescent Research, 19(4), 468-491. https://doi.org/10.1177/074355840325886 2

Newman, B. R., \& Newman, P. R. (2011). Development through life: A psychosocial approach $\left(5^{\text {th }}\right.$ ed.). Belmont: Cengeage learning.

Orth, U., Robins, R. W., Widaman, K. F., \& Conger, R. D. (2014). Is low self-esteem a risk factor for depression? Findings from a longitudinal study of Mexicanorigin youth. Development Psychology, 1, 622-633.

https://doi.org/10.1037/a0033817

Park, K., \& Yang, T.-C. (2017). The long-term effects of self-esteem on depression: The roles of alcohol and substance uses during young adulthood, Sociol $Q, 48(6), 607-$ 616.

https://doi.org/10.1038/ng.3564.Distinct

Prasetia, D. N., \& Hartati, S. (2014). Hubungan antara kesepian dengan penyesuaian diri pada mahasiswa (studi korelasi pada mahasiswa tahun pertama Fakultas Psikologi Universitas Diponegoro). Empati, 3(1), 47-56. Diakses dari https://ejournal3.undip.ac.id/index.php/e mpati/article/viewFile/7479/7239

Prihatiningsih, E., \& Wijayanti, Y. (2019). Gangguan mental emosionl siswa sekolah dasar. Higeia Journal of Public Mental Health Research and Development, 2(2), 
$252-262$.

https://doi.org/10.15294/higeia.v3i2.2602 4

Reid, G. M., Holt, M. K., Bowman, C. E., Espelage, D. L., \& Green, J. G. (2016). Perceived social support and mental health among first-year college students with histories of bullying victimization. Journal of Child and Family Studies, 25(11), 3331-3341. https://doi.org/10.1007/s10826-016-04777

Richardson, T., Elliott, P., \& Roberts, R. (2017). Relationship between loneliness and mental health in students. Journal of Public Mental Health, 16(2), 48-54. https://doi.org/10.1108/JPMH-03-20160013

Rohrmann, S., Schmid, M., Vandeleur, C. L., Barth, J., Eichholzer, M., \& Richard, A. (2017). Loneliness is adversely associated with physical and mental health and lifestyle factors: Results from a Swiss national survey. Plos One, 12(7), e0181442.

https://doi.org/10.1371/journal.pone.0181 442

Ruberman, L. (2014). Challenges in the transition to college: The perspective of the therapist back home. American Journal of Psychotherapy, 68(1), 103115.

DOI:

10.1176/appi.psychotherapy.2014.68.1.10 3

Ryff, C. D., \& Keyes, C. L. M. (1996). The structure of psychological well-being. Journal of Personality and Social Psychology, 35(5), 719-727. https://doi.org/10.2307/2093340

Stickley, A., Koyanagi, A., Koposov, R., Blatný, M., Hrdlička, M., Schwab-Stone, M., \& Ruchkin, V. (2016). Loneliness and its association with psychological and somatic health problems among Czech, Russian and U.S. adolescents. BMC Psychiatry, https://doi.org/10.1186/s12888-016-08292

Schneiderman, N., Ironson, G., \& Siegel, S. D. (2005). Stress and health: Psychological, behavioral, and biological determinants. Annual Review of Clinical Psychology, l(1), 607-628. https://doi.org/10.1146/annurev.clinpsy.1. 102803.144141

Umiroh, S. N. (2019). Hubungan antara loneliness dan homesickness pada mahasiswa Fakultas Psikologi Universitas Padjadjaran (skripsi). Universitas Padjadjaran, Bandung, Indonesia.

Verger, P., Guagliardo, V., Gilbert, F., Rouillon, F., \& Kovess-Masfety, V. (2010). Psychiatric disorders in students in six French universities: 12-month prevalence, comorbidity, impairment and help-seeking. Social Psychiatry and Psychiatric Epidemiology, 45(2), 189199. https://doi.org/10.1007/s00127-0090055-Z

Vidiawati, D., Iskandar, S., \& Agustian, D. (2018). Masalah kesehatan jiwa pada mahasiswa baru di sebuah universitas di Jakarta. EJournal Kedokteran Indonesia, $5(1)$.

https://doi.org/10.23886/ejki.5.7399.2733

Wei, M., Russell, D. W., \& Zakalik, R. A. (2005). Adult attachment, social selfefficacy, self-disclosure, loneliness, and subsequent depression for freshman college students: A longitudinal study. Journal of Counseling Psychology, 52(4), 602. https://psycnet.apa.org/doi/10.1037/00220167.52.4.602

Wenzlaff, R. M., \& Bates, D. E. (1998). Unmasking a cognitive vulnerability to depression: how lapses in mental control reveal depressive thinking. Journal of Personality and Social Psychology, 75(6), 1559-1571. 
https://psycnet.apa.org/doi/10.1037/00223514.75.6.1559

World Health Organisation. (1994). A user's guide to the self-report questionnaire $(S R Q)$. Geneva: World Health Organization. Diakses dari https://apps.who.int/iris/bitstream/handle/ 10665/61113/WHO_MNH_PSF_94.8.pdf ?sequence $=1 \&$ is Allowed $=\mathrm{y}$ 